\title{
V1/V2-directed antibodies elicited in RV144 vaccinees bind to a structurally polymorphic site
}

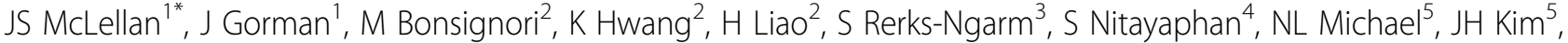 \\ BF Haynes ${ }^{2}$, PD Kwong ${ }^{1}$
}

From AIDS Vaccine 2012

Boston, MA, USA. 9-12 September 2012

\section{Background}

An immune correlates study of the RV144 vaccine trial demonstrated that elicitation of V1/V2-directed antibodies was inversely associated with infection risk. In addition, a sieve analysis of breakthrough infections identified residue 169 in the V2 loop as a site of immune pressure. Antibodies $\mathrm{CH} 58$ and $\mathrm{CH} 59$ were isolated from RV144 vaccinees and were shown to neutralize some Tier 1 isolates.

\section{Methods}

The epitopes for $\mathrm{CH} 58$ and $\mathrm{CH} 59$ were identified by peptide-mapping and alanine-scanning. Antigen-binding fragments (Fabs) were generated by proteolysis, and crystal structures of the $\mathrm{CH} 58$ and $\mathrm{CH} 59$ Fabs in complex with a linear V2 peptide were determined to 1.7 and $1.5 \AA$, respectively. Surface plasmon resonance was used to determine the kinetics of antibody binding to recombinant env-derived proteins.

\section{Results}

The crystal structures reveal that $\mathrm{CH} 58$ recognizes V2 residues $167-176$ as an $\alpha$-helix and residues $177-181$ as an extended coil. In contrast, CH59 recognizes residues 168173 as coil, with residues $174-176$ as a short $3_{10}$ helix. Both antibodies form hydrogen bond or salt-bridge interactions with the side chain of Lys169, the imputed site of immune pressure. The conformations of $\mathrm{V} 2$ recognized by $\mathrm{CH} 58$ and $\mathrm{CH} 59$ differ markedly from the $\beta$-strand conformation recognized by the broadly neutralizing antibody PG9. All three antibodies bound with high affinity to the same gp120 protein, suggesting that V2 residues 167-176 can adopt multiple conformations on a shed gp120.

${ }^{1}$ National Institutes of Health, Bethesda, MD, USA

Full list of author information is available at the end of the article

\section{Conclusion}

Since PG9 is broadly neutralizing and recognizes V2 as a $\beta$-strand, and because $\mathrm{CH} 58$ and $\mathrm{CH} 59$ neutralize only some Tier 1 isolates and recognize alternative conformations of $\mathrm{V} 2$, these data suggest that the $\beta$-strand conformation of V2 may be favored in the viral spike, whereas alternative V2 conformations may be favored on shed gp120s. If true, then vaccine immunogens may need to have the V1/V2 region stabilized in the $\beta$-strand conformation in order to elicit broadly neutralizing antibodies.

\section{Author details}

'National Institutes of Health, Bethesda, MD, USA. ${ }^{2}$ The Duke Human Vaccine Institute, Durham, NC, USA. ${ }^{3}$ Department of Disease Control, Bangkok, Thailand. ${ }^{4}$ Department of Retrovirology and AFRIM, Bangkok, Thailand. ${ }^{5}$ U.S. Military HIV Research Program, Rockville, MD, USA.

Published: 13 September 2012

\section{doi:10.1186/1742-4690-9-S2-P107}

Cite this article as: McLellan et al:: V1/V2-directed antibodies elicited in RV144 vaccinees bind to a structurally polymorphic site. Retrovirology 2012 9(Suppl 2):P107.

Submit your next manuscript to BioMed Central and take full advantage of:

- Convenient online submission

- Thorough peer review

- No space constraints or color figure charges

- Immediate publication on acceptance

- Inclusion in PubMed, CAS, Scopus and Google Scholar

- Research which is freely available for redistribution 